\begin{tabular}{|l|l|l||}
\hline \multicolumn{2}{|c|}{ PublisherInfo } \\
\hline \hline PublisherName & $:$ & BioMed Central \\
\hline \hline PublisherLocation & $:$ & London \\
\hline \hline PublisherImprintName & $:$ & BioMed Central \\
\hline \hline
\end{tabular}

\title{
Venous thrombosis and tunnelled infusion catheters
}

\begin{tabular}{||l|l|l||}
\hline \multicolumn{2}{|c||}{ ArticleInfo } \\
\hline \hline ArticleID & $:$ & 4247 \\
\hline \hline ArticleDOI & $:$ & $10.1186 /$ ccf-2000-2622 \\
\hline \hline ArticleCitationID & $:$ & 2622 \\
\hline \hline ArticleSequenceNumber & $:$ & 35 \\
\hline \hline ArticleCategory & $:$ & Paper Report \\
\hline \hline ArticleFirstPage & $:$ & 1 \\
\hline \hline ArticleLastPage & $:$ & 3 \\
\hline \hline & $:$ & RegistrationDate : 2000-11-23 \\
ArticleHistory & $:$ & OnlineDate \\
\hline \hline ArticleCopyright & $:$ & Current Science Ltd2000-11-23 \\
\hline \hline ArticleGrants & $:$ & \\
\hline \hline ArticleContext & $:$ & 1305433 \\
\hline \hline
\end{tabular}


Jeremy Bewley, Affl

Affl Bristol Royal Infirmary, UK

\section{Keywords}

Catheters and catheterisation complications, vein access, vein thrombosis

\section{Comments}

This article further develops the debate regarding the best route for central venous access, a procedure which is essential in the effective management of most critically ill patients. However, the study is limited by its retrospective analysis, lack of randomisation and poor follow-up. These methodological concerns aside, however the authors offer further evidence to support the argument to avoid the subclavian route where possible.

\section{Introduction}

This article addresses the problem of central venous thrombosis. It points out that thrombosis of a central vein may result in the permanent loss of the thrombosed vein and the ipsilateral extremity for central access in the future, at a time when central venous access may be at a premium. It is therefore incumbent on those who place central venous catheters to reduce the occurrence of this complication. Radiologists at Indiana University Hospital placed 774 tunnelled infusion catheters between 1993 and 1996. In 1994 there was a change from the use of subclavian (SC) catheters to internal jugular (IJ) catheters because of concerns regarding possible thrombosis.

\section{Methods}

. Telephone follow-up on 279 catheters in 238 patients

. Patients suspected of having venous thrombosis were evaluated with ultrasound and/or venography 


\section{Results}

A total of 166 catheters were placed via the SC vein and 113 were placed via the IJ vein, mostly in oncology patients. SC catheters were sited for a longer period than IJ catheters (103 versus 79 days). There was a similar infection rate at 0.25-0.32 infections per 100 catheter days. A total of 21 patients had a thrombosis with a mean time to thrombosis of 36 days for SC catheters and 142 days for IJ catheters (statistically significant). Of 143 patients with a SC catheter, 18 had a thrombosis compared with only three out of 95 with an IJ catheter (statistically significant). There was no relationship between thrombosis and catheter size, side of insertion, sex of the patient or indication for catheter placement.

\section{References}

1. Trerotola SO, Kuhn-Fulton J, Johnson MS, Shah H, Ambrosius WT, Kneebone PH: Tunnelled infusion catheters: increased incidence of symptomatic venous thrombosis after subclavian versus internal jugular venous access. Radiology. 2000, 217: 89-93.

This PDF file was created after publication. 